\title{
Effect of incision on visual outcomes after implantation of a trifocal diffractive IOL
}

\author{
Shasha Xue, Guiqiu Zhao*, Xiaoni Yin, Jing Lin, Cui Li, Liting Hu, Lin Leng and Xuejiao Yang
}

\begin{abstract}
Background: To evaluate visual acuity, corneal astigmatism and corneal higher-order aberrations (HOAs) after implantation of trifocal diffractive IOLs operated with either a corneal steep-axis incision or $135^{\circ}$ incision.

Method: This prospective study enrolled patients randomly assigned to different groups. According to preoperative corneal astigmatism, 101 eyes of 77 patients were assigned into group $A_{1}(0 \sim 0.50 \mathrm{D})$ or $A_{2}(0.51 \sim 1.00 \mathrm{D})$ with a corneal steep-axis incision or group $B_{1}(0 \sim 0.50 \mathrm{D})$ or $\mathrm{B}_{2}(0.51 \sim 1.00 \mathrm{D})$ with a $135^{\circ}$ incision. Visual acuity, corneal astigmatism and corneal higher-order aberrations (HOAs) were followed-up for 3 months.

Results: Corneal astigmatism in group $A_{2}$ significantly decreased 3 months after surgery $(P<0.01)$ and was significantly lower than that in group $B_{2} 1$ day, 2 weeks, 1 month, and 3 months postoperatively (all values of $P<0.01$ ). The following parameters were better in group $A_{2}$ than in group $B_{2}$ : uncorrected intermediate visual acuity (UIVA) at 1 day, 2 weeks, 1 month, and 3 months ( $P=0.00,0.00,0.01,0.01$, respectively); uncorrected distance visual acuity (UDVA) at 1 day and 2 weeks $(P=0.00,0.01)$; and uncorrected near visual acuity (UNVA) at 1 day, 2 weeks, and 1 month postoperatively $(P=0$. $00,0.01,0.02$, respectively).
\end{abstract}

Conclusions: After a corneal steep-axis incision, patients with preoperative corneal astigmatism of $0.51 \mathrm{D}$ to $1.00 \mathrm{D}$ exhibited reduced corneal astigmatism and achieved better UIVA and early postoperative UDVA/UNVA.

Trial registration: Retrospectively Registered Trials ISRCTN10086721, 23/06/2018.

Keywords: Cataract, Incision, Trifocal IOL, Corneal astigmatism

\section{Background}

Patients' expectations regarding refractive outcomes and spectacle independence have increased substantially, and both cataract patients and refractive patients have the same demands [1]. Multifocal IOLs were developed with the target of reducing spectacle dependence, which can provide patients with near and distance visual restoration after cataract surgery [2]. However, intermediate vision is limited because no specific focus is provided for this distance. Trifocal diffractive IOL designs have shown their capability to provide effective uncorrected intermediate visual acuity (UIVA) restoration without degradation of uncorrected distance visual acuity (UDVA) or uncorrected near visual acuity (UNVA). This new concept of IOL has confirmed good performance for visual outcomes, patient satisfaction and spectacle independence [3-10].

\footnotetext{
* Correspondence: zhaoguiqiu_good@126.com

The Affiliated Hospital of Qingdao University, No.16, Jiangsu Road, Qingdao, China
}

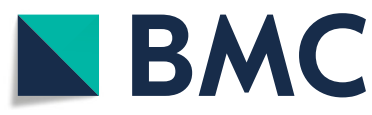

(C) The Author(s). 2018 Open Access This article is distributed under the terms of the Creative Commons Attribution 4.0 International License (http://creativecommons.org/licenses/by/4.0/), which permits unrestricted use, distribution, and reproduction in any medium, provided you give appropriate credit to the original author(s) and the source, provide a link to the Creative Commons license, and indicate if changes were made. The Creative Commons Public Domain Dedication waiver (http://creativecommons.org/publicdomain/zero/1.0/) applies to the data made available in this article, unless otherwise stated.
Patients' preoperative corneal astigmatism is critical to the choice of trifocal diffractive IOL, which is a key factor influencing the visual acuity and refractive outcomes postoperatively. Many studies have shown that the location of the corneal incision has an impact on postoperative corneal astigmatism and higher-order aberrations (HOAs), such as degradation of vision at night, halos and glare [11]. However, there is no research on the effect of incisions on visual outcomes after implantation of trifocal diffractive IOLs. This study aimed to evaluate visual acuity, corneal astigmatism and corneal HOAs after implantation of a trifocal diffractive IOL operated with either a corneal steep-axis incision or a $135^{\circ}$ incision.

\section{Methods \\ Patients}

In this prospective comparative study, 101 eyes of 77 patients undergoing cataract surgery with implantation 
of a trifocal diffractive IOL (AT LISA tri 839MP, Carl Zeiss Meditec, Germany) at the Affiliated Hospital of Qingdao University between January 2016 and December 2017 were enrolled. All eyes were divided into two groups: group A including 49 eyes of 37 patients with a $2.8 \mathrm{~mm}$ clear corneal incision at the steep-axis and group B including 52 eyes of 40 patients with a $2.8 \mathrm{~mm}$ clear corneal incision at $135^{\circ}$. According to the preoperative corneal astigmatism, groups $\mathrm{A}$ and $\mathrm{B}$ were separated into two subgroups: $\mathrm{A}_{1}(0 \sim 0.50 \mathrm{D}$ with 22 eyes), $\mathrm{A}_{2}$ (0.51 1.00 D with 27 eyes), $\mathrm{B}_{1}(0 \sim 0.50 \mathrm{D}$ with 23 eyes), and $\mathrm{B}_{2}(0.51 \sim 1.00 \mathrm{D}$ with 29 eyes). The inclusion criteria were cataract or presbyopia patients who had preexisting corneal astigmatism of less than $1.00 \mathrm{D}$ and seeking spectacle independence suitable for refractive lens exchange. The exclusion criteria were patients with a history of previous ocular surgery or ocular diseases, such as ocular inflammation, keratopathy, glaucoma, retinopathy or optic neuropathy.

The research adhered to the tenets of the Declaration of Helsinki and was approved by the ethics committee of the Affiliated Hospital of Qingdao University. A consent form were signed by all patients who were adequately informed and voluntary participated in the study.

\section{Examination protocol}

Complete preoperative and 1-day, 2-week, 1-month, and 3 -month postoperative ophthalmological examinations were performed in all cases, including monocular visual acuity (logMAR), Goldmann applanation tonometry, slit-lamp examination, funduscopy, manifest refraction, optical biometry (IOL Master 500; Carl Zeiss Meditec), and measurement of total corneal astigmatism and corneal aberration (both with a Galilei G2, Ziemer ophthalmic systems AG, Port, Switzerland). Visual acuities including preoperative corrected distance visual acuity (CDVA), postoperative UDVA, UIVA and UNVA were measured. The classifications of astigmatic axial length with the rule (WTR) $\left(90^{\circ} \pm 30^{\circ}\right)$, against the rule (ATR) $\left(0^{\circ}\right.$ to $30^{\circ}$ or $150^{\circ}$ to $\left.180^{\circ}\right)$, and oblique $\left(30^{\circ}\right.$ to $60^{\circ}$ or $120^{\circ}$ to $\left.150^{\circ}\right)$ were used. The calculation of surgically induced astigmatism (SIA) adopted the Jaffe/Clayman vector analysis [12]. The corneal aberrations considered a pupil aperture of $3.5 \mathrm{~mm}$ and were calculated and recorded with the Zernike coefficient.

\section{Surgical procedure}

All surgeries were performed by the same experienced surgeon who was masked to the patients' data before the surgery. Sutureless $2.8-\mathrm{mm}$ main corneal incisions either on the corneal steep-axis or at $135^{\circ}$ were set up in the navigation system by the same experimenter prior to the surgical procedure. After manual capsulorhexis and phacoemulsification, the trifocal diffractive IOL was inserted into the capsular bag through the main corneal incision using a specific injector. A postoperative topical therapy based on a combination of levofloxacin, nebcin and dexamethasone eye drops were prescribed to be applied four times daily for 1 week.

\section{Intraocular lens}

The AT Lisa tri 839MP is a diffractive trifocal preloaded IOL with a $6.0 \mathrm{~mm}$ biconvex optic, an overall length of $11.0 \mathrm{~mm}$, and a posterior surface with a sphericity of $0.18 \mu \mathrm{m}$. The near add is $+3.33 \mathrm{D}$, and the intermediate add is $+1.66 \mathrm{D}$. Its design allocates $50 \%$ of light to far, $20 \%$ to intermediate, and $30 \%$ to near vision. The central $4.34 \mathrm{~mm}$ follows the described trifocal design, and the peripheral part is only bifocal.

\section{Statistical analysis}

SPSS statistics software package version 22.0 was used for statistical analysis. Kolmogorov-Smirnov test was used to check the normality of the data distribution. When parametric analysis was possible, Student's t-tests for paired data were performed for all parameter comparisons. Otherwise, the Wilcoxon signed rank test was applied to assess the significance of differences between examinations. A power analysis was performed with $G^{*}$ Power software, and figures were made by GraphPad Prism. In all cases, the same level of significance $(P<0.05)$ was used.

\section{Results}

The study enrolled 101 eyes of 77 patients with a mean age of 59.33 years ranging from 43.00 to 77.00 years. There was no significant difference in age between the groups. The mean preoperative anterior chamber depth $(\mathrm{ACD})$ and axial length $(\mathrm{AL})$ were $3.21 \mathrm{~mm}$ (standard deviation [SD]: 0.40; median: 3.33; range: 2.54 to $3.94 \mathrm{~mm}$ ) and $23.99 \mathrm{~mm}$ (SD: 1.42; median: 23.54; range: 21.91 to $27.51 \mathrm{~mm}$ ), respectively. There were no statistically significant differences in preoperative ACD or AL between groups (Table 1).

\section{Corneal astigmatism}

There were no statistically significant differences between 3-month postoperative and preoperative corneal astigmatism in groups $\mathrm{A}_{1}, \mathrm{~B}_{1}$, or $\mathrm{B}_{2}(P=0.17,0.15,0.22$, respectively). However, corneal astigmatism in group $\mathrm{A}_{2} 3$ months postoperatively was significantly lower than preoperatively $(P<0.01)$. There were no statistically significant differences between group $A_{1}$ and group $B_{1} 1$ day, 2 weeks, 1 month, or 3 months postoperatively $(P=0.32,0.73,0.42,0.29$, respectively), but corneal astigmatism in group $\mathrm{A}_{2}$ was significantly lower than group $B_{2} 1$ day, 2 weeks, 1 month, and 3 months postoperatively (all $P<0.01$ ) (Table 2 ).

The proportion of WTR in group $\mathrm{A}_{1}$ declined from $59.1 \%$ preoperatively to $40.9 \% 3$ months postoperatively, 
Table 1 Preoperative and Postoperative Clinical Date

\begin{tabular}{|c|c|c|c|c|c|c|}
\hline $\begin{array}{l}\text { Parameters } \\
\text { mean } \pm \text { SD } \\
\text { median (range) }\end{array}$ & Group $A_{1}$ & Group $B_{1}$ & $\begin{array}{l}\mathrm{A}_{1} / \mathrm{B}_{1} \\
(P)\end{array}$ & Group $A_{2}$ & Group $B_{2}$ & $\begin{array}{l}\mathrm{A}_{2} / \mathrm{B}_{2} \\
(P)\end{array}$ \\
\hline Age (y) & $\begin{array}{l}59.23 \pm 7.12 \\
57.00(51.00 \text { to } 74.00)\end{array}$ & $\begin{array}{l}61.52 \pm 7.86 \\
62.00(43.00 \text { to } 77.00)\end{array}$ & 0.31 & $\begin{array}{l}57.22 \pm 10.86 \\
55.00(51.00 \text { to } 76.00)\end{array}$ & $\begin{array}{l}59.62 \pm 7.54 \\
59.00(43.00 \text { to } 75.00)\end{array}$ & 0.28 \\
\hline $\mathrm{ACD}(\mathrm{mm})$ & $\begin{array}{l}3.15 \pm 0.36 \\
3.26 \text { (2.60 to } 3.78)\end{array}$ & $\begin{array}{l}3.24 \pm 0.41 \\
3.34 \text { (2.54 to } 3.81)\end{array}$ & 0.45 & $\begin{array}{l}3.29 \pm 0.41 \\
3.36 \text { (2.54 to } 3.94)\end{array}$ & $\begin{array}{l}3.17 \pm 0.43 \\
3.33 \text { (2.54 to } 3.78)\end{array}$ & 0.89 \\
\hline $\mathrm{AL}(\mathrm{mm})$ & $\begin{array}{l}23.68 \pm 1.16 \\
23.49(21.96 \text { to } 26.45)\end{array}$ & $\begin{array}{l}24.29 \pm 1.53 \\
24.37 \text { (22.00 to } 26.84)\end{array}$ & 0.14 & $\begin{array}{l}24.21 \pm 1.56 \\
24.44(21.91 \text { to } 27.51)\end{array}$ & $\begin{array}{l}23.78 \pm 1.36 \\
23.53(21.96 \text { to } 26.74)\end{array}$ & 0.30 \\
\hline $\begin{array}{l}\text { Preoperative } \\
\text { UDVA }\end{array}$ & $\begin{array}{l}0.52 \pm 0.18 \\
0.52(0.22 \text { to } 1.00)\end{array}$ & $\begin{array}{l}0.58 \pm 0.16 \\
0.60 \text { (0.30 to } 0.82)\end{array}$ & 0.23 & $\begin{array}{l}0.56 \pm 0.16 \\
0.60(0.22 \text { to } 0.82)\end{array}$ & $\begin{array}{l}0.56 \pm 0.17 \\
0.52 \text { (0.22 to } 0.92)\end{array}$ & 0.85 \\
\hline $\begin{array}{l}\text { Preoperative } \\
\text { CDVA }\end{array}$ & $\begin{array}{l}0.40 \pm 0.14 \\
0.40 \text { (0.10 to } 0.70)\end{array}$ & $\begin{array}{l}0.47 \pm 0.12 \\
0.40(0.20 \text { to } 0.70)\end{array}$ & 0.24 & $\begin{array}{l}0.49 \pm 0.15 \\
0.52(0.22 \text { to } 0.82)\end{array}$ & $\begin{array}{l}0.50 \pm 0.18 \\
0.52 \text { (0.10 to } 0.82)\end{array}$ & 0.34 \\
\hline Spherical Refraction $^{a}(\mathrm{D})$ & $\begin{array}{l}-0.11 \pm 0.21 \\
0.00(-0.50 \text { to } 0.25)\end{array}$ & $\begin{array}{l}-0.13 \pm 0.24 \\
0.00(-0.50 \text { to } 0.25)\end{array}$ & 0.67 & $\begin{array}{l}-0.07 \pm 0.25 \\
0.00(-0.50 \text { to } 0.25)\end{array}$ & $\begin{array}{l}-0.07 \pm 0.23 \\
0.00(-0.50 \text { to } 0.25)\end{array}$ & 0.94 \\
\hline Cylindrical Refraction $^{a}(\mathrm{D})$ & $\begin{array}{l}-0.34 \pm 0.21 \\
-0.38(-0.75 \text { to } 0.00)\end{array}$ & $\begin{array}{l}-0.37 \pm 0.24 \\
-0.50(-0.75 \text { to } 0.00)\end{array}$ & 0.81 & $\begin{array}{l}-0.34 \pm 0.16 \\
-0.25(-0.50 \text { to } 0.00)\end{array}$ & $\begin{array}{l}-0.54 \pm 0.25 \\
-0.50(-1.00 \text { to } 0.00)\end{array}$ & 0.00 \\
\hline $\mathrm{SE}^{a}(\mathrm{D})$ & $\begin{array}{l}-0.28 \pm 0.22 \\
-0.25(-0.63 \text { to } 0.25)\end{array}$ & $\begin{array}{l}-0.32 \pm 0.23 \\
-0.38(-0.75 \text { to } 0.13)\end{array}$ & 0.59 & $\begin{array}{l}-0.25 \pm 0.24 \\
-0.25(-0.63 \text { to } 0.25)\end{array}$ & $\begin{array}{l}-0.34 \pm 0.26 \\
-0.38(-1.00 \text { to } 0.13)\end{array}$ & 0.18 \\
\hline
\end{tabular}

a months postoperation

while ATR increased from 27.3 to $45.5 \%$.The WTR of group $B_{1}$ decreased from 52.2 to $39.1 \%$, while ATR increased from 34.8 to $43.5 \%$. The WTR of group $\mathrm{A}_{2}$ decreased from 48.1 to $37.0 \%$, while ATR increased from 29.6 to $37.1 \%$. The WTR of group $B_{2}$ decreased from 48.3 to $27.6 \%$, while ATR increased from 27.6 to $34.5 \%$. However, the oblique of group $B_{2}$ increased from $24.1 \%$ preoperatively to $37.9 \% 3$ months postoperatively, but no obvious changes were found in groups $A_{1}, B_{1}$, or $A_{2}$ (13.6 to $13.6 \%, 13.0$ to $17.4 \%, 22.2$ to $25.9 \%$, respectively). (Fig. 1).

No significant differences in surgically induced astigmatism (SIA) were detected between group $A_{1}$ and group $B_{1}$ nor between group $A_{2}$ and group $B_{2} 3$ months postoperatively ( $P=0.61,0.82$, respectively). (Fig. 2$)$.

\section{Visual acuity}

There were no significant differences in preoperative UDVA and CDVA between the subgroups (Table 1). Postoperative visual acuity in each group was definitely better than preoperatively. No statistically significant differences in UDVA, UIVA, or UNVA between group $A_{1}$ and $B_{1}$ were found 1 day, 2 weeks, 1 month, or 3 months postoperatively (all values of $P>0.05$ ). However, the UIVA of group $A_{2}$ was significantly better than that of group $B_{2} 1$ day, 2 weeks, 1 month, and 3 months postoperatively $(P=$ $0.00,0.00,0.01,0.01$, respectively), while UDVA 1 day and 2 weeks $(P=0.00,0.01)$ and UNVA 1 day, 2 weeks, and 1 month postoperatively $(P=0.00,0.01,0.02$, respectively)in group $A_{2}$ were better than those in group $B_{2}$.However, there were no significant differences in UDVA

Table 2 Preoperative and Postoperative Corneal Astigmatism Data (D)

\begin{tabular}{|c|c|c|c|c|c|c|}
\hline $\begin{array}{l}\text { Groups } \\
\text { mean } \pm \text { SD median } \\
\text { (range) }\end{array}$ & Preoperation & $\begin{array}{l}1 \text { Day } \\
\text { Postoperation }\end{array}$ & $\begin{array}{l}2 \text { Weeks } \\
\text { Postoperation }\end{array}$ & $\begin{array}{l}1 \text { Month } \\
\text { Postoperation }\end{array}$ & $\begin{array}{l}3 \text { Months } \\
\text { Postoperation }\end{array}$ & $p^{a}$ \\
\hline$A_{1}$ & $\begin{array}{l}0.37 \pm 0.07 \\
0.39(0.23 \text { to } 0.49)\end{array}$ & $\begin{array}{l}0.68 \pm 0.32 \\
0.82(0.20 \text { to } 1.26)\end{array}$ & $\begin{array}{l}0.64 \pm 0.22 \\
0.60(0.26 \text { to } 1.05)\end{array}$ & $\begin{array}{l}0.55 \pm 0.17 \\
0.55(0.25 \text { to } 0.86)\end{array}$ & $\begin{array}{l}0.42 \pm 0.12 \\
0.44(0.22 \text { to } 0.61)\end{array}$ & $\begin{array}{l}0.17 \\
(\text { power }=50.64 \%)\end{array}$ \\
\hline$A_{2}$ & $\begin{array}{l}0.73 \pm 0.11 \\
0.70(0.58 \text { to } 0.99)\end{array}$ & $\begin{array}{l}0.63 \pm 0.26 \\
0.66(0.26 \text { to } 1.27)\end{array}$ & $\begin{array}{l}0.48 \pm 0.12 \\
0.45(0.29 \text { to } 0.86)\end{array}$ & $\begin{array}{l}0.49 \pm 0.09 \\
0.54(0.36 \text { to } 0.60)\end{array}$ & $\begin{array}{l}0.44 \pm 0.09 \\
0.45(0.25 \text { to } 0.56)\end{array}$ & $\begin{array}{l}0.00 \\
(\text { power = 100\%) }\end{array}$ \\
\hline $\mathrm{B}_{1}$ & $\begin{array}{l}0.40 \pm 0.07 \\
0.41(0.27 \text { to } 0.49)\end{array}$ & $\begin{array}{l}0.80 \pm 0.46 \\
0.88(0.20 \text { to } 1.87)\end{array}$ & $\begin{array}{l}0.66 \pm 0.23 \\
0.62(0.26 \text { to } 1.00)\end{array}$ & $\begin{array}{l}0.60 \pm 0.22 \\
0.57(0.25 \text { to } 1.00)\end{array}$ & $\begin{array}{l}0.47 \pm 0.18 \\
0.53(0.12 \text { to } 0.88)\end{array}$ & $\begin{array}{l}0.15 \\
\text { (power }=52.65 \%)\end{array}$ \\
\hline $\mathrm{B}_{2}$ & $\begin{array}{l}0.73 \pm 0.12 \\
0.68(0.58 \text { to } 0.99)\end{array}$ & $\begin{array}{l}1.01 \pm 0.38 \\
0.91 \text { (0.66 to } 2.16)\end{array}$ & $\begin{array}{l}0.79 \pm 0.30 \\
0.69(0.48 \text { to } 1.54)\end{array}$ & $\begin{array}{l}0.79 \pm 0.28 \\
0.83(0.45 \text { to } 1.83)\end{array}$ & $\begin{array}{l}0.69 \pm 0.21 \\
0.70(0.43 \text { to } 1.35)\end{array}$ & $\begin{array}{l}0.22 \\
(\text { power }=31.10 \%)\end{array}$ \\
\hline $\mathrm{A}_{1} / \mathrm{B}_{1}(P)$ & $\begin{array}{l}0.21 \\
\text { (power = 40.89\%) }\end{array}$ & $\begin{array}{l}0.32 \\
(\text { power }=25.94 \%)\end{array}$ & $\begin{array}{l}0.73 \\
\text { (power = 8.83\%) }\end{array}$ & $\begin{array}{l}0.42 \\
\text { (power = 21.03\%) }\end{array}$ & $\begin{array}{l}0.29 \\
\text { (power = 28.57\%) }\end{array}$ & - \\
\hline$A_{2} / B_{2}(P)$ & $\begin{array}{l}0.98 \\
(\text { power }=5.00 \%)\end{array}$ & $\begin{array}{l}0.00 \\
(\text { power }=99.61 \%)\end{array}$ & $\begin{array}{l}0.00 \\
\text { (power = 99.96\%) }\end{array}$ & $\begin{array}{l}0.00 \\
\text { (power = 99.99\%) }\end{array}$ & $\begin{array}{l}0.00 \\
(\text { power }=100 \%)\end{array}$ & - \\
\hline
\end{tabular}

${ }^{\mathrm{a} C o m p a r i s o n}$ between preoperation and 3 months postoperation 


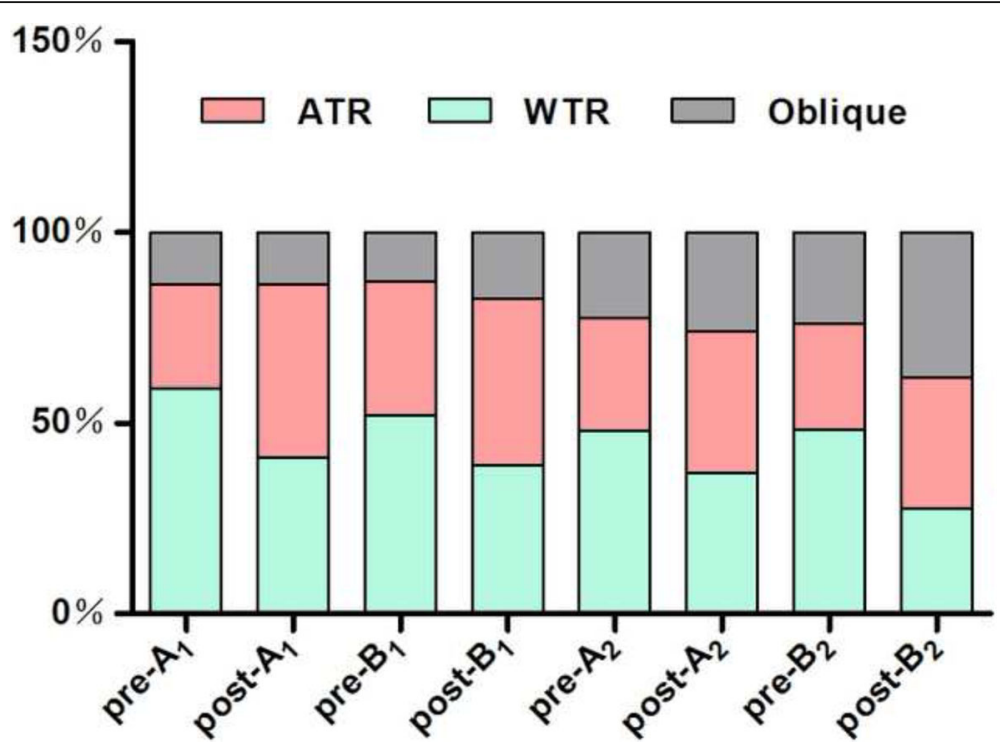

Fig. 1 Preoperative and postoperative proportion of WTR, ATR, Oblique in each subgroup

1 month or 3 months postoperatively $(P=0.26,0.44)$ or in UNVA 3 months postoperatively $(P=0.45)$ (Table 3$)$.

\section{Corneal aberration}

There were no significant differences in preoperative total corneal wave-front aberration, root mean square value of corneal higher-order aberrations (RMS HOAs), spherical aberration (SA), coma, or trefoil between group A and group B. Total corneal wave-front aberrations were much higher 1 day, 2 weeks, and 1 month postoperatively in group B than in group A (all $P<0.01$ ). There were no statistically significant differences in total corneal wave-front aberrations 3 months postoperatively or in RMA HOAs, SA, coma, or trefoil 1 day, 2 weeks,
1 month, and 3 months postoperatively between group A and group $B$ (all $P>0.05$ ). (Fig. 3).

In group A, RMS HOAs and trefoil 1 day and 2 weeks postoperatively increased apparently (all $P<0.05$ ), while there were no differences in RMS HOAs or trefoil 1 month or 3 months postoperatively. There were no obvious changes in total corneal wave-front aberrations, SA or coma after surgery (all $P>0.05$ ). (Fig. 3).

In group $\mathrm{B}$, the level of total corneal wave-front aberrations, RMS HOAs, and trefoil 1 day and 2 weeks postoperatively (all values of $\mathrm{P}<0.01$ ) significantly increased, but there were no differences 1 month or 3 months postoperatively. There were no obvious changes in SA or coma after surgery (all $P>0.05$ ). (Fig. 3 ).

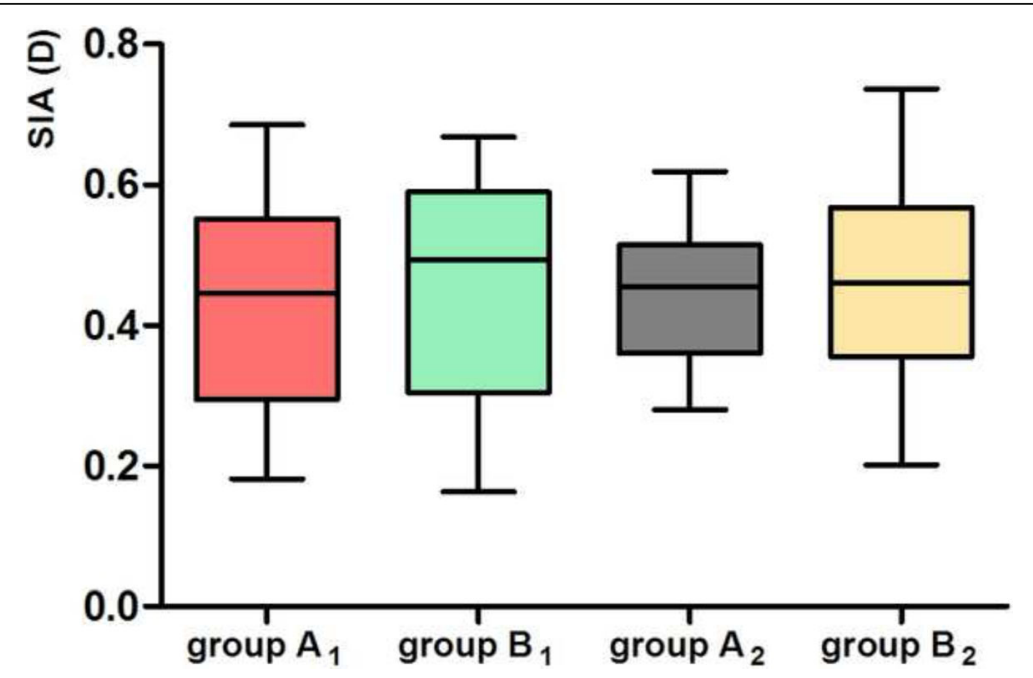

Fig. $2 \mathrm{SIA}$ at 3 months postoperation in group $A_{1}, B_{1}, A_{2}, B_{2}$ 
Table 3 Postoperative Visual Acuity Data (logMAR)

\begin{tabular}{|c|c|c|c|c|c|c|}
\hline $\begin{array}{l}\text { Visions } \\
\text { mean } \pm \text { SD median (range) }\end{array}$ & Group $A_{1}$ & Group $B_{1}$ & $\begin{array}{l}\mathrm{A}_{1} / \mathrm{B}_{1} \\
(P)\end{array}$ & Group $A_{2}$ & Group $B_{2}$ & $\begin{array}{l}\mathrm{A}_{2} / \mathrm{B}_{2} \\
(P)\end{array}$ \\
\hline $\begin{array}{l}\text { UDVA } \\
\text { (1 day) }\end{array}$ & $\begin{array}{l}0.06 \pm 0.05 \\
0.10(0.00 \text { to } 0.15)\end{array}$ & $\begin{array}{l}0.03 \pm 0.06 \\
0.00(-0.08 \text { to } 0.20)\end{array}$ & $\begin{array}{l}0.11 \\
\text { (power = 55.88\%) }\end{array}$ & $\begin{array}{l}-0.01 \pm 0.04 \\
0.00(-0.08 \text { to } 0.10)\end{array}$ & $\begin{array}{l}0.06 \pm 0.08 \\
0.00 \text { (0.00 to } 0.22)\end{array}$ & $\begin{array}{l}0.00 \\
(\text { power }=99.27 \%)\end{array}$ \\
\hline $\begin{array}{l}\text { UDVA } \\
\text { (2 weeks) }\end{array}$ & $\begin{array}{l}0.01 \pm 0.06 \\
0.00(-0.08 \text { to } 0.10)\end{array}$ & $\begin{array}{l}0.00 \pm 0.05 \\
0.00(-0.08 \text { to } 0.10)\end{array}$ & $\begin{array}{l}0.72 \\
(\text { power = 14.75\%) }\end{array}$ & $\begin{array}{l}-0.01 \pm 0.03 \\
0.00(-0.08 \text { to } 0.05)\end{array}$ & $\begin{array}{l}0.02 \pm 0.05 \\
0.00(-0.08 \text { to } 0.10)\end{array}$ & $\begin{array}{l}0.01 \\
(\text { power }=85.12 \%)\end{array}$ \\
\hline $\begin{array}{l}\text { UDVA } \\
\text { (1 month) }\end{array}$ & $\begin{array}{l}-0.01 \pm 0.04 \\
0.00(-0.08 \text { to } 0.05)\end{array}$ & $\begin{array}{l}0.00 \pm 0.05 \\
0.00(-0.08 \text { to } 0.10)\end{array}$ & $\begin{array}{l}0.65 \\
(\text { power = 17.99\%) }\end{array}$ & $\begin{array}{l}-0.01 \pm 0.03 \\
0.00(-0.08 \text { to } 0.05)\end{array}$ & $\begin{array}{l}0.00 \pm 0.05 \\
0.00(-0.08 \text { to } 0.10)\end{array}$ & $\begin{array}{l}0.26 \\
(\text { power }=22.68 \%)\end{array}$ \\
\hline $\begin{array}{l}\text { UDVA } \\
\text { (3 months) }\end{array}$ & $\begin{array}{l}-0.02 \pm 0.04 \\
0.00(-0.08 \text { to } 0.05)\end{array}$ & $\begin{array}{l}-0.01 \pm 0.04 \\
0.00(-0.08 \text { to } 0.05)\end{array}$ & $\begin{array}{l}0.40 \\
(\text { power }=20.62 \%)\end{array}$ & $\begin{array}{l}-0.01 \pm 0.03 \\
0.00(-0.08 \text { to } 0.00)\end{array}$ & $\begin{array}{l}0.00 \pm 0.05 \\
0.00(-0.08 \text { to } 0.10)\end{array}$ & $\begin{array}{l}0.44 \\
(\text { power }=22.68 \%)\end{array}$ \\
\hline $\begin{array}{l}\text { UIVA } \\
\text { (1 day) }\end{array}$ & $\begin{array}{l}0.10 \pm 0.06 \\
0.10 \text { (0.00 to } 0.22)\end{array}$ & $\begin{array}{l}0.09 \pm 0.06 \\
0.10(0.00 \text { to } 0.20)\end{array}$ & $\begin{array}{l}0.59 \\
(\text { power = 13.68\%) }\end{array}$ & $\begin{array}{l}0.03 \pm 0.05 \\
0.00(0.00 \text { to } 0.15)\end{array}$ & $\begin{array}{l}0.12 \pm 0.11 \\
0.10(0.00 \text { to } 0.30)\end{array}$ & $\begin{array}{l}0.00 \\
(\text { power }=98.76 \%)\end{array}$ \\
\hline $\begin{array}{l}\text { UIVA } \\
\text { (2 weeks) }\end{array}$ & $\begin{array}{l}0.06 \pm 0.05 \\
0.10(-0.08 \text { to } 0.10)\end{array}$ & $\begin{array}{l}0.03 \pm 0.06 \\
0.00(-0.08 \text { to } 0.20)\end{array}$ & $\begin{array}{l}0.14 \\
(\text { power = 55.88\%) }\end{array}$ & $\begin{array}{l}0.02 \pm 0.04 \\
0.00(0.00 \text { to } 0.10)\end{array}$ & $\begin{array}{l}0.07 \pm 0.05 \\
0.10 \text { (0.00 to } 0.15)\end{array}$ & $\begin{array}{l}0.00 \\
(\text { power }=99.25 \%)\end{array}$ \\
\hline $\begin{array}{l}\text { UIVA } \\
\text { (1 month) }\end{array}$ & $\begin{array}{l}0.03 \pm 0.05 \\
0.00(-0.08 \text { to } 0.15)\end{array}$ & $\begin{array}{l}0.02 \pm 0.05 \\
0.00(-0.08 \text { to } 0.15)\end{array}$ & $\begin{array}{l}0.55 \\
\text { (power = 16.24\%) }\end{array}$ & $\begin{array}{l}0.02 \pm 0.03 \\
0.00(0.00 \text { to } 0.10)\end{array}$ & $\begin{array}{l}0.07 \pm 0.08 \\
0.10(-0.08 \text { to } 0.20)\end{array}$ & $\begin{array}{l}0.01 \\
(\text { power }=92.08 \%)\end{array}$ \\
\hline $\begin{array}{l}\text { UIVA } \\
\text { (3 months) }\end{array}$ & $\begin{array}{l}0.01 \pm 0.03 \\
0.00(-0.08 \text { to } 0.05)\end{array}$ & $\begin{array}{l}0.01 \pm 0.04 \\
0.00(-0.08 \text { to } 0.10)\end{array}$ & $\begin{array}{l}0.57 \\
(\text { power }=5.00 \%)\end{array}$ & $\begin{array}{l}0.00 \pm 0.04 \\
0.00(-0.08 \text { to } 0.10)\end{array}$ & $\begin{array}{l}0.04 \pm 0.06 \\
0.05(-0.08 \text { to } 0.10)\end{array}$ & $\begin{array}{l}0.01 \\
(\text { power }=89.46 \%)\end{array}$ \\
\hline $\begin{array}{l}\text { UNVA } \\
\text { (1 day) }\end{array}$ & $\begin{array}{l}0.11 \pm 0.07 \\
0.10(0.00 \text { to } 0.20)\end{array}$ & $\begin{array}{l}0.12 \pm 0.05 \\
0.10 \text { (0.00 to } 0.20)\end{array}$ & $\begin{array}{l}0.50 \\
(\text { power = 13.52\%) }\end{array}$ & $\begin{array}{l}0.10 \pm 0.05 \\
0.10(0.00 \text { to } 0.20)\end{array}$ & $\begin{array}{l}0.19 \pm 0.09 \\
0.20(0.10 \text { to } 0.30)\end{array}$ & $\begin{array}{l}0.00 \\
(\text { power }=99.82 \%)\end{array}$ \\
\hline $\begin{array}{l}\text { UNVA } \\
\text { (2 weeks) }\end{array}$ & $\begin{array}{l}0.08 \pm 0.04 \\
0.10(0.00 \text { to } 0.15)\end{array}$ & $\begin{array}{l}0.09 \pm 0.03 \\
0.10 \text { (0.00 to } 0.15)\end{array}$ & $\begin{array}{l}0.22 \\
\text { (power = 23.84\%) }\end{array}$ & $\begin{array}{l}0.10 \pm 0.05 \\
0.10(0.00 \text { to } 0.20)\end{array}$ & $\begin{array}{l}0.14 \pm 0.05 \\
0.10(0.00 \text { to } 0.20)\end{array}$ & $\begin{array}{l}0.01 \\
(\text { power }=90.47 \%)\end{array}$ \\
\hline $\begin{array}{l}\text { UNVA } \\
\text { (1 month) }\end{array}$ & $\begin{array}{l}0.06 \pm 0.06 \\
0.05 \text { (0.00 to } 0.15)\end{array}$ & $\begin{array}{l}0.08 \pm 0.03 \\
0.10 \text { (0.00 to } 0.10)\end{array}$ & $\begin{array}{l}0.19 \\
\text { (power = 40.00\%) }\end{array}$ & $\begin{array}{l}0.09 \pm 0.04 \\
0.10(0.00 \text { to } 0.15)\end{array}$ & $\begin{array}{l}0.12 \pm 0.05 \\
0.10(0.00 \text { to } 0.20)\end{array}$ & $\begin{array}{l}0.02 \\
(\text { power }=78.86 \%)\end{array}$ \\
\hline $\begin{array}{l}\text { UNVA } \\
\text { (3 months) }\end{array}$ & $\begin{array}{l}0.05 \pm 0.06 \\
0.05(-0.08 \text { to } 0.15)\end{array}$ & $\begin{array}{l}0.04 \pm 0.05 \\
0.00(-0.08 \text { to } 0.10)\end{array}$ & $\begin{array}{l}0.59 \\
(\text { power = 14.75\%) }\end{array}$ & $\begin{array}{l}0.09 \pm 0.05 \\
0.10(0.00 \text { to } 0.20)\end{array}$ & $\begin{array}{l}0.10 \pm 0.05 \\
0.10(0.00 \text { to } 0.20)\end{array}$ & $\begin{array}{l}0.45 \\
(\text { power }=18.24 \%)\end{array}$ \\
\hline
\end{tabular}

\section{Discussion}

The trifocal diffractive IOLs have shown perfect visual restoration of intermediate vision without degradation of distance or near vision. It's worth noting that its efficacy is affected by many factors, among which incision location, SIA and preoperative corneal astigmatism are of great importance. Owing to personal surgical practice, some surgeons tend to choose a habitual incision location.
Mojzis et al. [13] adopted temporal clear corneal incision, Florian et al. [14] chose incision at the corneal steep-axis, and Matthias Müller et al. [1] used incisions at twelve o'clock on the cornea. Effective restoration of postoperative distance vision, intermediate vision, and near vision was obtained in their studies. However, the influence of the location of corneal incision on postoperative residual corneal astigmatism and visual acuities after implantation

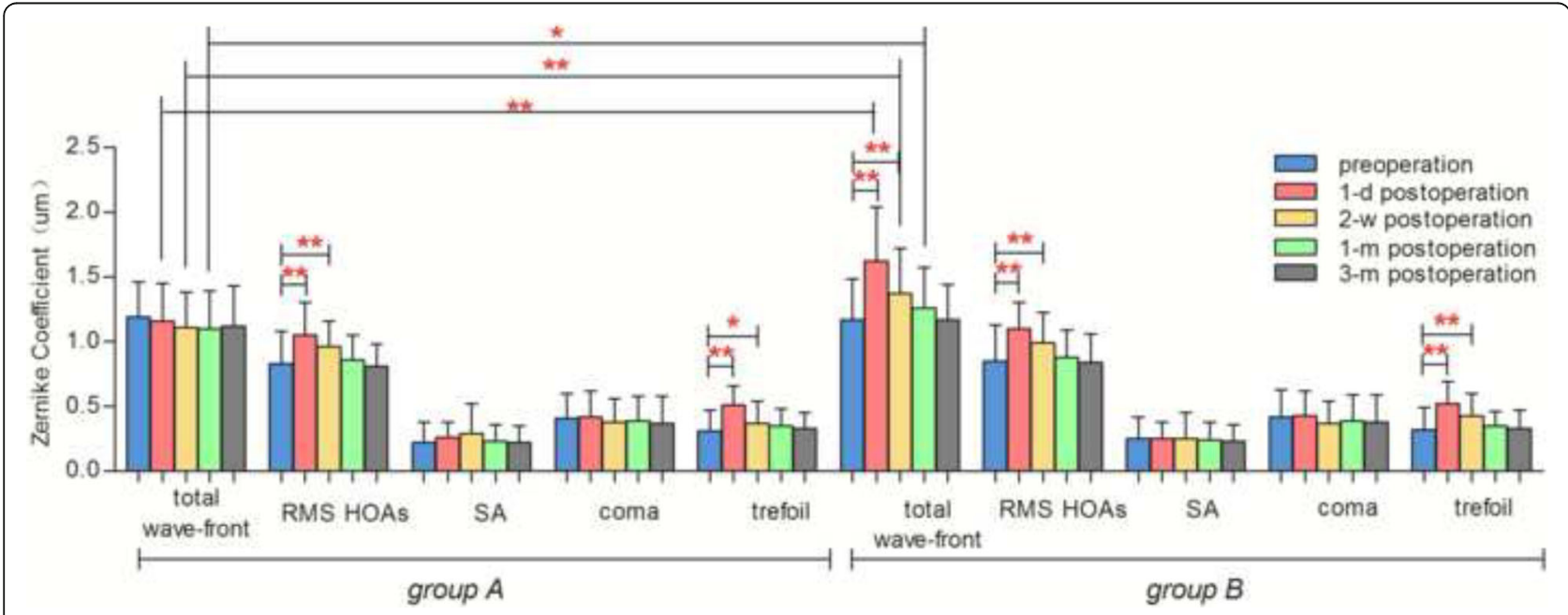

Fig. 3 Preoperative and postoperative total corneal wave-front, RMS HOAs, SA, coma, trefoil in each subgroup, ${ }^{*} P<0.05,{ }^{* *} P<0.01$ 
of the trifocal diffractive IOLs was unclear. Therefore, we comprehensively assessed the performance of a steep-axis incision and $135^{\circ}$ incision. We found that after a corneal steep-axis incision, patients with preoperative corneal astigmatism of $0.51 \mathrm{D}$ to $1.00 \mathrm{D}$ achieved reduced corneal astigmatism and better UIVA and early postoperative UDVA/UNVA.

In our study, we found that when patients' preoperative corneal astigmatism was under $0.50 \mathrm{D}$, there were no significant differences in postoperative vision or corneal astigmatism between a steep-axis incision and $135^{\circ}$ incision. Because currently used incision sizes are small, even on the micro scale, their interference with the cornea is not significant. Therefore, surgeons can select an appropriate incision based upon their own operational preferences. As for patients with preoperative corneal astigmatism of $0.51 \mathrm{D}$ to $1.00 \mathrm{D}$, making a corneal incision at the steep-axis can reduce postoperative corneal astigmatism and provide patients with better UIVA and better early postoperative UDVA/UNVA. This kind of trifocal IOL design allocates $50 \%$ of light to far, $20 \%$ to intermediate and 30\% to near vision. Owing to the proportion of light allocation, the influence of corneal astigmatism on visual acuity after implantation with the trifocal diffractive IOLs is UDVA > UNVA > UIVA, but the sensitivity of corneal astigmatism is UIVA > UNVA > UDVA.

Corneal astigmatism was much higher in the early period after the surgery due to corneal edema, but the steep-axis incision shaped the cornea more regularly than the $135^{\circ}$ incision after cataract operation. This difference produced early postoperative UDVA, UIVA, and UNVA that were much better in patients with corneal steep-axis incision. With the healing of the corneal incision and fading of corneal edema, corneal astigmatism reduced and gradually became steady, and intermediate vision was more susceptible to corneal astigmatism, which maybe small but is indeed important for UIVA. This study is the first clinical study comparing the visual outcomes obtained with either corneal steep-axis incision or $135^{\circ}$ incision and showing the realistic benefits of corneal steep-axis incision in patients implanted with trifocal diffractive IOLs.

There were no significant differences in the SIA between a steep-axis incision and $135^{\circ}$ incision in our study. Postoperative astigmatism depends on preoperative corneal astigmatism and SIA. Since incisions currently are small or even on a micro scale in cataract surgery, the value of SIA is not large enough to markedly affect visual acuity [11]. There is an inseparable relationship between corneal astigmatism and vision quality after implantation with a trifocal diffractive IOL. The recommended corneal astigmatism from cataract surgery with trifocal diffractive IOL is no more than 0.75 D. However, Elizabeth et al. [5] chose patients with preoperative corneal astigmatism under 1.00 D, and Peter Mojzis [15] and Florian Tobias selected 1.25 D [16] at most, but Thomas et al. [17] expanded the range to $1.50 \mathrm{D}$. Our study opted for preoperative corneal astigmatism equal to or less than $1.00 \mathrm{D}$. Excellent visual outcomes were obtained, and a significant improvement in UDVA, UIVA, and UNVA was found in all these studies with appropriate incision locations. Whether there is an acceptable range of preoperative corneal astigmatism with implantation of trifocal diffractive IOLs needs further study.

We found a drift phenomenon from WTR to ATR postoperatively with a corneal steep-axis incision and $135^{\circ}$ incision. This finding was consistent with Cui Y's $[18,19]$ studies, which showed the same phenomenon after cataract surgery. However, the impact of the astigmatic axial on visual acuity was oblique $>$ ATR $>$ WTR astigmatism [20]. In our study, a higher percentage of oblique astigmatism but a much lower percentage of WTR astigmatism was found postoperatively in group $\mathrm{B}_{2}$ compared with those in group $\mathrm{A}_{2}$. This finding maybe another factor that contributed to better outcomes in group $A_{2}$ than in group $B_{2}$.

We detected that there was no difference in corneal HOAs between steep-axis incision and $135^{\circ}$ incision, but both corneal HOAs from the different incisions were much higher in the early period after the surgery. Some patients achieved vision of $0.00 \log$ MAR or better but still suffered from degradation vision at night, halos and glare. This phenomenon may be due to the increase in postoperative HOAs. Mojzis et al. [3] reported that after surgery for trifocal diffractive IOLs, there was a significant decrease in ocular aberrations and internal aberrations, while there was no statistically significant difference between preoperative and postoperative corneal aberrations. In our study, corneal HOAs increased with steep-axis and $135^{\circ}$ incisions due to the existence of a surgical incision and early postoperative corneal edema. However, it reduced gradually and was not different compared to preoperative HOAs 3 months postoperatively. This finding was consistent with Florian T.A Kretz's discovery [14] that negative effects were not disturbing and were a temporary phenomenon that reduced over time. However, total corneal wave-front aberration was much higher with the $135^{\circ}$ incision because of its larger, early postoperative corneal astigmatism than that with the steep-axis incision that shaped the cornea more regularly.

\section{Conclusions}

In summary, steep-axis incision may be an ideal incision choice for patients with preoperative corneal astigmatism of $0.51 \mathrm{D}$ to $1.00 \mathrm{D}$ for trifocal diffractive IOL implantation. However, for patients with preoperative corneal astigmatism under $0.50 \mathrm{D}$, surgeons can select the appropriate incision based on their own preferences. 


\section{Abbreviations}

ACD: Anterior chamber depth; AL: Axial length; ATR: Against the rule; CDVA: Corrected distance visual acuity; HOAs: Higher-order aberrations; RMS HOAs: Root mean square value of corneal higher-order aberrations; SA: Spherical aberration; SE: Spherical equivalent; SIA: Surgically induced astigmatism; UDVA: Uncorrected distance visual acuity; UIVA: Uncorrected intermediate visual acuity; UNVA: Uncorrected near visual acuity; WTR: With the rule

\section{Acknowledgments}

We acknowledge the professional help of American Journal Experts for correcting all linguistic errors in the manuscript, including the section of the abstract.

\section{Funding}

It was funded by the National Natural Science Foundation of China $(81470609,81300730)$ and the National Natural Science Foundation of Shandong (ZR2017BH025). The funders played an important role in study design, data collection and analysis, decision to publish, or preparation of the manuscript.

\section{Availability of data and materials}

The data analyzed during the current study are available from the corresponding author on reasonable request.

\section{Authors' contributions}

SSX was responsible for its design, collection of data, analysis and interpretation of results and wrote the first draft of the manuscript. GQZ participated in its design and revise of manuscript. XNY was involved in data collection. JL, CL, XJY and LL helped revise of manuscript; LTH conceived the study design. All authors have read and approved the final manuscript.

\section{Ethics approval and consent to participate}

The research adhered to the tenets of the Declaration of Helsinki and was approved by the Affiliated Hospital of Qingdao University ethics committee. All patients were adequately informed about the study and signed a consent form. It is available for review by the Editor of this journal if necessary.

\section{Consent for publication}

Details, images, or videos reported within the manuscript are consented for publication

\section{Competing interests}

The authors declare that they have no competing interests.

\section{Publisher's Note}

Springer Nature remains neutral with regard to jurisdictional claims in published maps and institutional affiliations.

Received: 26 October 2017 Accepted: 6 July 2018

Published online: 13 July 2018

\section{References}

1. Kretz FT, Müller M, Gerl M, et al. Binocular function to increase visual outcome in patients implanted with a diffractive trifocal intraocular lens. BMC Ophthalmol. 2015;15:110.

2. Calladine D, Evans JR, Shah S, Leyland M. Multifocal versus monofocal intraocular lenses after cataract extraction. Sao Paulo Med J. 2015 Feb:133(1):68

3. Mojzis P, Peña-García P, Liehneova I, Ziak P, Alió JL. Outcomes of a new diffractive trifocal intraocular lens. J Cataract Refract Surg. 2014;40:60-9.

4. Alió JL, Montalbán R, Peña-García P, Soria FA, Vega-Estrada A. Visual outcomes of a trifocal aspheric diffractive intraocular lens with micro incision cataract surgery. J Refract Surg. 2013;29:756-61.

5. Law EM, Aggarwal RK, Kasaby H. Clinical outcomes with a new trifocal intraocular lens. Eur J Ophthalmol. 2014:24:501-8.

6. Cochener B, Vryghem J, Rozot $P$, et al. Visual and refractive outcomes after implantation of a fully diffractive trifocal lens. Clin Ophthalmol. 2012;6:1421-7.

7. Sheppard AL, Shah S, Bhatt U, Bhogal G, Wolffsohn JS. Visual outcomes and subjective experience after bilateral implantation of a new diffractive trifocal intraocular lens. J Cataract Refract Surg. 2013;39:343-9.
8. Lesieur G. Outcomes after implantation of a trifocal diffractive IOL [article in French]. J Fr Ophthalmol. 2012;35:338-42.

9. Voskresenskaya A, Pozdeyeva N, Pashtaev N, Batkov Y, Treushnicov V, Cherednik V. Initial results of trifocal diffractive IOL implantation. Graefes Arch Clin Exp Ophthalmol. 2010;248:1299-306.

10. Mendicute J, Kapp A, Lévy P, Krommes G, Arias-Puente A, Tomalla M, Bouchut P. Evaluation of visual outcomes and patient satisfaction after implantation of a diffractive trifocal intraocular lens. J Cataract Refract Surg. 2016:42(2):203-10.

11. He W, Zhu X, Du Y, Yang J, Lu Y. Clinical efficacy of implantation of toric intraocular lenses with different incision positions: a comparative study of steepaxis incision and non-steep-axis incision. BMC Ophthalmol. 2017;17(1):132.

12. Jaffe NS, Clayman HM. The pathophysiology of corneal astigmatism after cataract extraction. Trans Am Acad Ophthalmol Otolaryngol. 1975;79:615-30.

13. Mojzis P, Kukuckova L, Majerova K, Liehneova K, Piñero DP. Comparative analysis of the visual performance after cataract surgery with implantation of a bifocal or trifocal diffractive IOL. J Refract Surg. 2014 Oct;30(10):666-72.

14. Kretz FT, Breyer D, Diakonis VF, et al. Clinical Outcomes after Binocular Implantation of a New Trifocal Diffractive Intraocular Lens. J Ophthalmol. 2015;2015:962891.

15. Mojzis P, Majerova K, Hrckova L, Piñero DP. Implantation of a diffractive trifocal intraocular lens: one-year follow-up. J Cataract Refract Surg. 2015;41:1623-30

16. Kretz FT, Choi CY, Müller M, Gerl M, Gerl RH, Auffarth GU. Visual outcomes, patient satisfaction and spectacle independence with a trifocal diffractive intraocular Lens. Korean J Ophthalmol. 2016:30(3):180-91.

17. Kohnen T, Titke C, Bohm M. Trifocal intraocular Lens implantation to treat visual demands in various distances following Lens removal. Am J Ophthalmol. 2016;161:P71-7.

18. Cui Y, Meng Q, Guo H, Zeng J, Zhang H, Zhang G, Huang Y, Lan J. Biometry and corneal astigmatismin cataract surgery candidates from southern China. J Cataract Refract Surg. 2014;40(10):1661-9.

19. Özyol E, Özyol P. Analyses of surgically induced astigmatism and axis deviation in microcoaxial phacoemulsification. Int Ophthalmol. 2014;34(3):591-6.

20. Remón L, Monsoriu JA, Furlan WD. Influence of different types of astigmatism on visual acuity. J Optom. 2017;10(3):141-8.

\section{Ready to submit your research? Choose BMC and benefit from:}

- fast, convenient online submission

- thorough peer review by experienced researchers in your field

- rapid publication on acceptance

- support for research data, including large and complex data types

- gold Open Access which fosters wider collaboration and increased citations

- maximum visibility for your research: over $100 \mathrm{M}$ website views per year

At BMC, research is always in progress.

Learn more biomedcentral.com/submissions 